\title{
Entomologists' associations in the 19th century Russia: The story of the Entomological Committee of the Society of Friends of Natural Science
}

\author{
Объединения энтомологов в России XIX века: \\ История Энтомологической комиссии \\ Общества Аюбителей естествознания
}

\author{
G.G. Krivosheina \\ Г.Г. Кривошеина
}

S.I. Vavilov Institute for the History of Science and Technology, Baltiiskaia ul., 14, Moscow 125315 Russia. Институт истории естествознания и техники им. С.И. Вавилова, Балтийская ул., 14, Москва 125315 Россия.

KEY WORDS: history of entomology in Russia; scientific societies; Society of Friends of Natural Science, Anthropology, and Ethnography; OLEAE; A.P. Bogdanov; A.P. Fedchenko; V.F. Oshanin; V.N. Ul'ianin; N.K. Senger; E.K. Freimut.

КЛЮЧЕВЫЕ СЛОВА: история энтомологии в России; научные общества; Общество любителей естествознания, антропологии и этнографии; ОЛЕАЭ; А.П. Богданов; А.П. Федченко; В.Ф. Ошанин; В.Н. Ульянин; Н.К. Зенгер; Е.К. Фреймут.

ABSTRACT: The Russian Entomological Society dating back to 1859 was one of the first specialized scientific societies in Russia. However it was hardly the only one specialized association of entomologists in Russia. Multidisciplinary natural history societies also could establish entomological divisions of their own. The activities of these divisions was subject to their own regulations, they developed specialized research programs and usually had their own sources of financial support. The present paper deals with the history of one of such divisions - the Permanent Entomological Committee of the Society of Friends of Natural Science and its contribution to Russian entomology.

РЕЗЮМЕ: Русское энтомологическое общество, ведущее свою историю с 1859 г., было одним из первых специализированных научных обществ России. Однако оно не было единственным профессиональным объединением энтомологов в стране. В естественнонаучных обществах широкого профиля также могли существовать собственные энтомологические подразделения. Эти подразделения часто имели свой устав, собственные исследовательские программы и источники финансирования. В данной статье будет рассмотрена история создания одного из таких объединений - Постоянной энтомологической комиссии Общества любителей естествознания - и его вклад в развитие отечественной энтомологии.

\section{Introduction}

In the nineteenth century Russia natural history societies dominated among institutional bodies involved in research of natural and human resources of the country. All of them, university societies included, were nongovernmental voluntary associations with fixed membership. Their activity was rarely limited only to regular (or irregular) meetings where society members presented and discussed their recent scientific advances. However, it was both more extensive and diverse. Societies vividly responded to new challenges by initiating various research programs, organizing expeditions, establishing new research stations, laboratories, and teaching facilities.

Russian natural history societies were for the most part multidisciplinary. Their interests stretched over a wide range of disciplines from zoology, botany, and geology to anthropology, ethnography, and even archaeology. And the reason why this type of societies was in demand seems obvious enough. In provincial cities scientific community was thin and in order to establish a really working natural science society it was inevitable that all local academic scientists and amateurs of any kind were attracted, be that botanists, zoologists, geologists, or local historians. The same situation was true even for Moscow. When A.P. Bogdanov in 1863 conceived of creating a new natural

How to cite this article: Krivosheina G.G. 2018. Entomologists' associations in the 19th century Russia: The story of the Entomological Committee of the Society of Friends of Natural Science // Russian Entomol. J. Vol.27. No.4. P.451-458. doi: 10.15298/rusentj.27.4.14 
history society in addition to the already existing Moscow Society of Naturalists this was considered, at list by some Moscow naturalists, as an attempt to destroy not too numerous Moscow scientific community [Krivosheina, 2013]. Then again, history showed that Bogdanov's critics were wrong and Moscow scientists productively cooperated with the both societies.

In Saint-Petersbourg, as compared to provincial Russia, there was a quite different situation. The capital was the place where the Academy of Science resided and where Russian academic and intellectual elite was concentrated and specialized scientific societies closely cooperating with the Academy were the predominant type. They had been appearing here since the first quarter of the $19^{\text {th }}$ century. The first of them, St. Petersbourg Mineralogical Society, was established in 1817. It was followed by the Russian Geographical Society in 1845, Russian Entomological Society (RES) in 1859, and later on by some others.

However, societies, be they specialized or multidisciplinary, promptly responded to the needs of local scientific communities and Russian science a whole. RES was a good case in point. In the middle of the 19th century Petersbourg naturalists faced an apparent deficiency of natural history associations ${ }^{1}$, since the existing specialized societies did not cover all the branches of natural science. So when RES was established many Petersbourg zoologist (non-entomologists) and botanists came into it and for a certain period of time there functioned a botanical department [Medvedev, 2000]. Multidisciplinary societies, by the same token, answered the demands of the growing specialization of science by organizing specialized subdivisions within them. To all practical purposes this was much easier than to establish a new society, because it was considered an inner matter of a society and was decided by its Council. At the same time any new society which tried to get official standing had to be approved by the government and this procedure could take a lot of time and effort. That's exactly why the first anthropological body in Russia was established in 1864 as a division within the Society of Friends of Natural Science [Krivosheina, 2014], but it took twenty four more years before a separate anthropological society was officially approved ${ }^{2}$.

Unfortunately, in spite of the significant role that scientific societies played in Russian science in the 19th century their history, the more so history of their specialized divisions, still remains underestimated and understudied. The present paper deals with a story of rise and fall of one of such divisions, namely the Permanent Entomological Committee of the Society of Friends of Natural Science.
Entomological research during the first years of the Society of Friends of Natural Science

The Permanent Entomological Committee by the Society of Friends of Natural Science was established in 1866 , during the third year of society's existence. The society itself dated its history back to 1863 , when on October 14 professor of the Moscow University Anatolii Bogdanov and his students completed their work on constitution of the new scientific society which was named the Society of Friends of Natural Science ${ }^{3}$ (for further details see [Vucinich, 1971; Bradley, 2009; Krivosheina, 2013]. According to this constitution the society was being established for the purpose of "natural historical exploration of the governorates of the Moscow Educational District and promotion of natural science among the mass of the public" [Minutes, 1866: suppl.]. It should be recalled that educational districts were established in the course of the 1803 educational reform of Alexander I. Moscow Educational District included some ten governorates (Moscow, Vladimir, Kaluga, Kostroma, and other) though their number could change from time to time. In spring 1864 constitution of the new society was approved by the Ministry of National Education and on May 14 its first official meeting was held.

The young society pursued a wide range of academic interests: from geology (public geological excursions of the President of the society Grigorii Shchurovskii were very popular in Moscow), meteorology, and botany to zoology and anthropology. As for geography of society's activities, at first, due to insufficient funds, it was limited to the territory of Moscow and its vicinity and only occasionally covered more remote uezds and governorates of the Moscow Educational District.

In the field of zoology, and entomology in particular, OLEAE was primarily focused on enlargement and development of collections of the University Zoological Museum that came under Bogdanov's direction in 1863 [Lyubarsky, 2009]. Describing the museum entomological collection Secretary of the Society Nikolai Senger indicated that at that time "University collection of insects was rather fair if lepidopterans and coleopterans were concerned but extremely poor in specimens of other orders" and moreover it "was short of our local fauna specimens" [Minutes, 1866: 158-159]. In order to fill this gap OLEAE conceived a program of systematic entomological study of the area of the Moscow Educational District. Many of the most active members of the Society including Bogdanov himself, his students Alexei Fedchenko, Vasilii Oshanin, Vasilii Ul'anin as

\footnotetext{
${ }^{1}$ The first multidisciplinary naturalists' society was established in St. Petersbourg at the instigation of the First Congress of Russian Naturalists in 1868 .

${ }^{2}$ Russian Anthropological Society was established in 1888 in St. Petersbourg.

${ }^{3}$ In 1867 the society changed its title into Imperial Society of Friends of Natural Science, Anthropology and Ethnography (OLEAE in Russian initials).
} 
well as some graduate and postgraduate students who had attended Bogdanov's course of zoology in the University but were specializing in other fields of natural science (Nikolai Malashkin, Viktor Meshaev, Alexander Pichugin, Piotr Piktorskii, Mikhail Varavva et al.) were eager to take part in this research, so that somebody noticed once that "the Society will never be short on collectors; we may even hope that their number will be growing with time" [Minutes, 1866: 27].

Already during the first summer season of 1864 OLEAE undertook fourteen excursions which were usually referred as "zoological" in Minutes of the Society but had predominantly entomological agenda. Most of the excursions were conducted around Moscow parks and gardens and in the nearest vicinity of the city (Bogorodskoe, Tsaritsino, Kuzminki, Khoroshovo) but some went out to the neighboring uezds (Mozhaisk, Dmitrov, Klin, Kolomna) [Minutes, 1866: 27]. Although they had covered only five of the thirteen uezds of the Moscow Governorate it was a good start. The same year the material gathered during these excursions was used to compile several collections of insect pests which were awarded two Major Silver Medals at the AllRussia Exhibition of Agricultural Produce, held in Moscow by the Moscow Society for Agriculture [Minutes, 1866: 52].

However promising, these were only the first steps and the leadership of the Society clearly understood that much more had to be done. So, in the run up to the new summer season of 1865 Bogdanov, Fedchenko, and Senger worked out Concise Advisory on Collecting Natural History Objects [Minutes, 1866: 123-134], which dealt with methods to collect and preserve animals, plants, rocks, and paleontological artifacts. It was presented at the ninth meeting of OLEAE on May 14, 1865 and was not only meant to help those members of the Society who were not proficient enough in doing natural history collections but, which was more important, it was addressed to everybody who was interested in natural science and could help the Society as collector. About half of Concise Advisory was devoted to insects and gave a clear and detailed description of how to collect and preserve insects, how to mount insect collections, what data had to be indicated for every specimen, what equipment, instruments, and field guides were needed and where collectors could buy them.

Concise Advisory also articulated the main goals of the Society in regard to entomology. There were three of them. The first catered to replenishment of collections of insects of the Moscow and adjacent governorates. Collectors were recommended to pay particular attention to insects belonging to the orders Hymenoptera, Hemiptera, Diptera, Neuroptera, and Orthoptera. The second goal consisted in the study of insect biology, including "the arrangement of collections of various stages of insect development, larvae of different stages, and pupae and $<\ldots>$ plants and their parts on which they were found" [Minutes, 1866: 128]. The third goal dealt with various aspects of applied entomology, in the first place, the study of "insect pests of shrubs, trees, field and garden plants, flowers, < . > orchards, and so on", in what connection "the very samples of the damage produced by them [pests - G.K.] — bark, leaves, roots, stems of plants with their galleries, nests, and so on are particularly desirable" [Minutes, 1866: 128].

The efforts of the authors of Concise Advisory were rewarded, so that already at the annual meeting of OLEAE on October 14, 1865 its Secretary Nikolai Senger could state with good reason that the Society was largely successful in the arrangement of its "Moscow entomological collection" [Minutes, 1866: 159]. In just two summer seasons of 1864-1865 more than ten thousand insect specimens were collected. By order of the Society they were studied and identified by Fedchenko (dipterans and hymenopterans), Piktorskii and Pichugin (lepidopterans), Senger (coleopterans), Ul'anin (orthopterans), and Oshanin (hemipterans). Already in February 1866 they presented preliminary results on identification of about eight thousand specimens [Minutes, 1866: 209-214].

The greatest bulk of work was done by Alexei Fedchenko who studied 3685 Diptera specimens collected in the Moscow and Yaroslavl Governorates and identified them as belonging to 619 species of 218 genera falling into 25 families. According to his estimate this amounted to about a quarter of the total number of dipterous species inhabiting the territory of the Moscow Educational District ${ }^{1}$. He also studied 1567 specimens of Hymenoptera and found out that they represented 290 species belonging to 77 genera. Vasilii Oshanin reported on his work on 1275 specimens of Hemiptera collected in the Moscow, Kaluga, Ryazan, and Tambov Governorates and attributed them to 112 species of true bugs and 45 species of homopterans. Vasilii Ul'anin presented the results of his identification of Orthoptera genuine (30 species of 16 genera) and Neuroptera together with Pseudoneuroptera ( 76 species belonging to 27 genera).

Naturally enough, the Society's interests in entomology were not limited to systematics and faunistics. If we look through its minutes for the years 1864-1866 we can find numerous observations on insect biology, development, and behaviour. Among the most interesting we may mention N. Senger's paper, containing one of the first detailed descriptions of biology and development of the lilac leafminer Gracilaria syringella F., 1794 (its outbreak occurred in Moscow and vicinity in 1864) [Minutes, 1866: 59]; V. Ul'anin's account on larval paedogenesis among gall midges, a phenomenon discovered in 1862 by Nikolai Wagner, professor of zoology of Kazan University [Wagner, 1862] and on a case of finding similar paedogenetic larvae "in the vicinity of Moscow, namely in a marshy wood lying between Petrovskii Park and Butyrki $<\ldots>$ under the 
bark of a birch tree stump" [Minutes, 1866: 134]. As a matter of fact, some of entomological observations present in the minutes might seem odd enough, e.g., the story of an amazing viability of a larva of Corethra plumicornis F., 1794 which over the course of several days for the purpose of microscopic study was for some hours immersed in glycerol under a coverslip and still managed to survive [Minutes, 1866: 134].

\section{Establishment of the Permanent Entomo-} logical Committee

During 1864-1866 inside OLEAE an entomological community was gradually taking shape. It incorporated firstly professors, graduate and postgraduate students $^{1}$ of Physico-Mathematical and Medical Faculties of Moscow University. Some had chosen zoology as their profession and some were specializing in different fields of science or medicine but took an interest in entomology. For the most part they were founding members of OLEAE but some, as e.g. Bogdanov's student Alexander Kroneberg, joined to the Society after it had been established. Secondly, this community included amateur entomologists, such as Nikolai Kertselli, an official at the Moscow branch of the Governing Senate, later a Secretary and a President of the OELAE Anthropological Department and curator of the Dashkov Ethnographical Museum [Koval', Teplitskaia, 2003: 94-95; Formosov, 2007: 65], or Director of Moscow Orphanage Alexei Umov ${ }^{2}$ [Bogdanov, 1889]. Unfortunately, there is almost no information on many of amateur entomologists mentioned in OLEAE minutes, e.g.several ladies of the large Kandinskii family, who regularly donated their collections to OLEAE.

Amateur entomologist Elizaveta Freimut [Val'kova, $2012,2014]$ was also related to this family and later on got married to a renowned Russian psychiatrist Viktor Kandinskii. Information on her life and work is extremely scarce. This is true for many Russian womenscientists of the 19th century. O. Val'kova, who has studied Freimut's biography, is right, noting that "We did not know $<\ldots>$ what was her education and fostering, when did her interest to natural science emerge, how did she acquire skills necessary for an experienced entomologist?" [Val'kova, 2014: 270]. However, the last question - how did Freimut acquire necessary entomological skills - seems to have an answer. She started her first collection of insects that she later donated to OLEAE in summer of 1865. Apparently it was not at all a coincidence that not long before the OLEAE had issued the above mentioned Concise Advisory on Collecting Natural History Objects that was provided to everyone interested. OLEAE members highly estimated Freimut as collector, so in February 1866 at the suggestion of Fedchenko, Oshanin, Ul'anin, and Senger she became a probation member [Minutes, 1866: 211, 220] and in November of the same year was elected a full member of the Society [Minutes, 1886: 31] .

By 1866 it became obvious that research of the insect fauna of the Moscow Educational District had significance of its own and to provide further progress in this field the Society needed to establish a specialized entomological division. So in the run up to the new summer season at the meeting on May 13, 1866 Fedchenko, Ul'anin, Bogdanov and several other members of the Society came out with a statement that read:

"We, the undersigned Members of the Society of Friends of Natural Science taking into consideration that exploration of the governorates of the Moscow Educational District in regard to entomology is one of the special goals of the Society, that this exploration has already been started by us, and that lastly it deserves special promotion on the part of the Society suggest to:

1) establish out of us a Permanent Entomological Committee as part of the Society of Friends of Natural Science which is to supervise all preparatory works in entomology of the Moscow Educational District, issue educational insect collections, carry excursions, draw up reports, communicate with other Entomological Societies and individual scientists, and so on.

2) regard as members of this Committee also other members of the Society, who will express their consent to the terms specified by the next paragraph.

3) allocate to the expenses of the Committee extra annual payments on the part of the members of the Committee, the amount of which is individually decided by each member.

4) entitle the Committee $<\ldots>$ to find the best ways to achieve the above mentioned goals and to lay down the rules of its inner management" [Minutes, 1866: 243-244].

This initiative was approved by the Society and Fedchenko was elected president and Ul'anin secretary of the Committee [Minutes, 1866: 244]. Soon Elizaveta Freimut and some other OLEAE members also joined the Committee.

\section{Activities of the Committee}

The summer season of 1866 proved to be rewarding to the Committee. The amount of insect specimens gathered by its members one and a half times exceeded that collected during the two previous years. According to the Society's annual report for 1865/1866 the Permanent Entomological Committee "during this summer carried 96 excursions and visited 41 localities. The first excursion took place on March 22, the last one - on September 14. During the excursions 17,550 insect specimens were collected (Diptera 7,700, Hemiptera 3,450 , Hymenoptera 2,700, Neuroptera 1,980, Coleoptera 1,180, Orthoptera 340, and Lepidoptera 200). Besides that 1,350 insects collected in the Dmitrov uezd

\footnotetext{
${ }^{1}$ Unlike Moscow Society of Naturalists, in OLEAE students were granted membership to the society.

${ }^{2} \mathrm{He}$ was the father of a well-known Russian physicist and philosopher Nikolai Umov.

3 A founding member of OLEAE, later the wife of Alexei Fedchenko.
} 
were delivered to the Society by the Kandinsii ladies and 100 insects of the Mozhaisk uezd - by O.A. Armfeldt ${ }^{3}$ " [Minutes, 1886: 11-12].

At the subsequent meetings in November $1866-$ May 1867 members of the Entomological Committee time and again reported on the progress of their work on arrangement, preservation and identification of insect specimens stored by the Society and on entomological observations during excursions conducted by the Committee. Alexei Fedchenko, president of the Committee, seemed to be the most prolific in this respect. For example, at one and the same meeting on November 27, 1866 he managed to present his observations on egg laying by biting midges Ceratopogon venustus Meigen, 1818 (=Probezzia seminigra Panzer, 1798); a report on a find in March in Neskuchny Garden in an old birch stump of a large amount of larvae of wood gnats Mycetobia pallipes Meigen, 1818 and on development of these larvae; on a find of a female of Tipula autumnalis Loew, 1846 with reduced wings and on cases of wing reduction in dipterous insects as a whole [Minutes, 1886: 22-27].

The Committee was also active in establishing contacts with entomological societies and individual entomologists in Russia and abroad and exchanging collections and scientific publications [Minutes, 1886: 256257]. This helped to considerably enlarge a collection of insects of the University Zoological Museum. Besides, these contacts appeared useful when several years later the Society faced a task to describe and identify an extensive entomological collection brought by Fedchenko from Turkestan. But for all that the main goal of the Committee, that is to compile a list of insects inhabiting the area of the Moscow Educational District, still remained unaccomplished, even though reports on the progress in this field routinely appeared in the pages of the minutes of the Society [Minutes, 1886: 2-29; 51 et al.].

However we need to keep in mind that the end of 1866 - beginning of 1867 was one of the most challenging periods in the life of OLEAE The Society was busy making preparations for the Ethnographical Exhibition (about this exhibition see [Raikov, 1959; Knight, 2001]), which was to be opened in Moscow on April 23, 1867. It was the first of a series of scientific exhibitions that made OLEAE popular all over Russia and abroad as well. Almost all members of the Society were in some way involved in preparation work and the main burden fell on the shoulders of the leaders of OLEAE and its Anthropological Division ${ }^{1}$ and members of the Committee for the organization of the exhibition. Among committee men of the latter there were many members of the Entomological Committee, including A. Bogdanov, N. Senger, A. Fedchenko, V. Oshanin, V. Ul'anin, and N. Kertselli. It's obvious enough that under such conditions anything that was not privy to the exhibition fell by the wayside.
After the closure of the exhibition the work on the insect lists was resumed and in 1868 Fedchenko, Oshanin, and Ul'anin prepared three of them (on Diptera, Orthoptera, and Hemiptera) for publication. They put a lot of effort in this work. First of all, the number of species about doubled as compared to preliminary lists presented in 1866 [Minutes, 1866: 209-214]. The number of dipteran species grew up from 619 to 1227 ; species of orthopterans together with neuropterans from 106 to 196; hemipterans - from 157 to 384 . Besides, the lists were supplied with extensive data on biology (habitats, time of emergence and egg laying, voltinism, et c) and development of certain species. Publication of the lists started in 1868. They appeared annually as separate issues of the sixth volume of the Izvestiia OLEAE (Proceedings of OLEAE). The first was the List of dipterous insects by Fedchenko [Fedchenko, 1868], the second - Ul'anin's neuropterous and orthopterous insects [Ul'anin, 1869], and the third — hemipterans by Oshanin [Oshanin, 1870].

It is not clear enough, why publication of the lists dragged on for three years but presumably the Society was strapped for money since the bulk of cash was spent on editions concerned with the Ethnographic Exhibition. Unfortunately, the faunistic series stopped at the third issue and the original plan to compile the lists of Hymenoptera, Lepidoptera, and Coleoptera of the governorates of the Moscow Educational District had never come true.

\section{The Fall of the Committee}

Publicity received by OLEAE after the Ethnographic Exhibition seemed to play a cruel joke with the Entomological Committee. New financial and organizing opportunities that opened up before the Society made it focus on major projects, so that early local projects, including that of entomological study of the governorates of the Moscow Educational District, were gradually receding into the background. Under the circumstances many of the most active members of the Entomological Committee turned to more promising projects. Vasilii Oshanin in early 1868 went abroad to Germany, France, and Italy to improve his knowledge in natural science. Tasked by the Society, he also made acquaintance with equipment and management of large aquaria and fish hatcheries, since OLEAE was planning to build in Moscow several public aquaria. In 1871 by order of OLEAE he travelled through South Caucasus and in 1872 moved to Tashkent where the OLEAE Turkestan Division was being established at that time. Nikolai Senger and Vasilii Ul'anin got involved into two new research programs on freshwater lakes and on Russian seas started by OLEAE in 1868 . The president of the Committee Alexei Fedchenko headed the OLEAE Turkestan expedition that continued from 1868 to 1872 ,

${ }^{1}$ At that period both anthropology and ethnography were within competence of this division. A separate Ethnographical Division was established in March 1867, on the very eve of the Exhibition. 
except for a short interval in the end of 1869 - early 1870 .

Beginning with 1869 a vast collection of animals and plants gathered by Fedchenko's Turkestan expedition started arriving at the Society. There are no data on the total number of the specimens but we know that animal collection of 1868-1869 alone amounted up to twenty thousand specimens, including more than sixteen thousand insects, among them 5,031 specimens of dipterans, 3,917 coleopterans, 3,476 hymenopterans, 1,390 hemipterans, and so on [Minutes, 1870: 19]. All the specimens had to be arranged and identified, at least preliminarily and members of the Entomological Committee took the entomological part of this task upon themselves [Minutes, 1870: 161-173]. They also attracted to this work some renowned entomologist from Russia and abroad, among them O. Bourmeister-Radoszkowski, S. Sol'skii, N. Ershov, F. Morawitz, H. de Saussure (Switzerland), R. McLachlan (Great Britain), G.L. Mayr and F.M. Brauer (Austria-Hungary), et al. Fedchenko handled all the work on dipterans as well as hymenopterans except for the sawflies (they were studied by Freimut), parasitoid and gall wasps. Ul'anin worked on orthopterans and neuropterans (and later on crustaceans), Kroneberg — on spiders. Oshanin studied hemipterous insects (as well as fish specimens ${ }^{1}$ ).

The Society was planning to publish in Izvestiia $O L E A E$ a series of issues under the title A.P. Fedchenko's Journey to Turkestan. So members of the Committee besides preparing their own contributions were also involved in the editing of the series as a whole. In addition they translated into Russian entomological papers prepared by foreign scientists, since the editorial policy of the Society unambiguously indicated that all scientific contributions should be published in Russian. Unfortunately, due to circumstances beyond the Society's control not all of its plans concerning the edition of Journey were realized. As it was mentioned above, in 1872 Oshanin left Moscow for Tashkent to head a school of sericulture. While in Moscow he worked strenuously on hemipteran collection and intended to prepare a whole issue on Turkestan Hemiptera. He even published a description of sixteen new bug species collected by Fedchenko in 1869 in the Zarafshan Valley [Bogdanov, 1888: 199-202]. But when he moved to Tashkent the Society for some unclear reasons failed to supply him with collections he needed to continue his study. If we consider OLEAE sent some parts of Fedchenko's collections to Great Britain or Austria, this fact seems rather odd. However that may be, he stopped his work on the collection and the issue on hemipterans was compiled by Odo Reuter, lecturer, later professor of zoology of the University of Helsinki [Reuter, 1887].

However in 1873 the Society and the Committee suffered a severe loss as Alexei Fedchenko died in Mont Blanc where he practiced in the run up to his expedition to the Pamirs. This tragic death brought to a stop the Turkestan expedition of OLEAE and made the Society change a bit the format of Journey, excluding some introductory chapters that were to be written by Fedchenko. Journey came out already after his death in 1874-1888 as separate issues of five volumes of Izvestiia OLEAE (vols 11, 19, 21, 26, 34) $)^{2}$. Out of a total of 22 issues ten were devoted to various groups of insects e.g. butterflies and moths [Ershov, 1874], beetles [Sol'skii, 1874, 1876], neuropterans [McLachlan, 1875], bees [Morawitz, 1875, 1876], etc. and one - to spiders [Kroneberg, 1875]. The issue on Diptera was not included into Journey series, though after Fedchenko died the Society sent his collection of dipterans to the German dipterologist F.H. Loew, who compiled a description of 93 new species of Turkestan Diptera [Minutes, 1871: 52-59].

The work on Fedchenko's collections was the last occasion that members of the Entomological Committee joined their effort to work on a major project. But while it was gathering pace the Committee itself wound down its activities. Nevertheless occasional reports on insect collections gathered by members of the Committee during their summer excursions still appeared on pages of the minutes of the Society [Minutes, 1886: 99102 etc.]. Elizaveta Freimut when she superseded Fedchenko as president of the Committee somewhen around 1870 tried to reanimate the Committee. However, the fact of this replacement was not mentioned in the minutes except for a short note that in early 1871 the Society allowed 400 rubles "for entomological excursions around the governorates of the Moscow Educational District to the president of the Entomological Committee Elizaveta Karlovna Freimut" [Minutes, 1871: 67]. But this hardly could improve the situation and in the middle of the 1870 s the Committee ceased to exist.

\section{Conclusion}

Since the establishment of the Academy of Science studying of the territory of Russia, its natural resources, its fauna and flora was considered an essential task of Russian science. Numerous expeditions, launched by the Academy and later by natural history societies or even some governmental structures, were sent to the faroff regions of the Empire, while the central, more easily accessible areas seemed to excite only passing interest. Thus, J.G. Fischer von Waldheim, professor of the Moscow University and the founder of the Moscow Society of Naturalists, declared that it would have been inexcusable and futile for any naturalists' learned society to ignore the area where it was established [Fischer v. Waldheim, 1812]. He even published Oryctographie du gouvernement de Moscou, dealing with physical description, geology, and paleontology of the Moscow Gouvernorate [Fischer v. Waldheim, 1837] but the soci-

${ }^{1}$ This refers to preliminary study of the specimens of fish; the issue on fish for A.P. Fedchenko's Journey to Turkestan was compiled by Karl Kessler [Kessler, 1874].

${ }^{2}$ For the story of their edition see [Val'kova, 2006]. Unfortunately, there are certain discrepancies when it comes to entomology. 
ety he presided preferred to explore more exotic areas. The first society that in 1863 proclaimed natural historical exploration of the territory of Central Russia to be its primal goal was OLEAE. Several years later after the First Congress of Russian Naturalists other university natural history societies established on the model of OLEAE [Proceedings, 1868: 2-62] joined to the study of European Russia.

The activities of the Permanent Entomological Committee were perfectly matched with the goal declared by OLEAE. It should be noted though, that the Committee was not the first to undertake a task of surveying the insects of the Moscow region. It had a predecessor. That was an eminent Russian naturalist Ivan Dvigubskii, who in 1802 presented a list of Moscow animals entitled Primitiae Faunae Mosquiensis, seu enumeratio animalium, quae sponte circa Mosquam vivunt as his doctoral thesis [Bogdanov, 1885]. The list included 707 species of insects. The Committee managed to enlarge it up to 1807 species. But we should bear in mind that the lists published by the Committee dealt only with several insect orders. The orders Lepidoptera, Coleoptera, and Hymenoptera were not covered and if they were the list would have been much longer. Unfortunately, the Committee, as compared to other OLEAE divisions, was not long-lived (it was in existence for a little more than a decade) and new horizons that opened up for OLEAE after the Ethnographic Exhibition brought its work to a stop. Nevertheless it laid the foundations of serious systematic research of the insect fauna of the Moscow region. Later this work was continued by the OLEAE zoological division and Faunistic Committee. The latter survived well through the 1917 revolution and was active until the Society was eliminated in early 1930s.

\section{References}

Bei-Bienko G.Ya. (ed.). 1969-1970. [A Field Guide to Insects of the European Part of the USSR. Vol.5. Dipterans, Fleas. In 2 parts]. Leningrad: Nauka Publ. Pt.1, 807 pp.; pt.2, 943 pp. [in Russian]

Bogdanov A.P. 1885. [Karl Frantsovich Roullier and his predecessors in the chair of zoology in the Imperial Moscow University] // Izvestiia OLEAE. Vol.43. No.2. P.1-215 [in Russian].

Bogdanov A.P. 1888. [Annals of zoological research of the Society during the first twenty five years of its existence. Vol.1. Faunistic research of the Society] // Izvestiia OLEAE. Vol.54. Col.1-494 [in Russian].

Bogdanov A.P. 1889. [Materials on the history of scientific and applied activities in Russia in the field of zoology and related branches of knowledge, foremost for the last 35 years (18501887). Vol.2] // Izvestia OLEAE. Vol.57. Without pagination [in Russian].

Bradley J. 2009. Voluntary Associations in Tsarist Russia. Science, Patriotism and Civil Society Cambridge Massachusetts, London England: Harvard University Press. 384 pp.

Ershov N.G. 1874. [A.P. Fedchenko's Journey to Turkestan: Butterflies and moths (Lepidoptera)] // Izvestiia OLEAE. Vol.11. No.2. P.1-128 [in Russian].

Fedchenko A.P. 1868. [A list of dipterous insects of the governorates of the Moscow Educational District] // Izvestiia OLEAE. Vol.6. No.1. Col.1-191 [in Russian].

Fisher v. Waldheim J.G. 1812. [Research on fossils present in the Moscow Governorate]. Moscow: University typography. 32 pp. [in Russian].
Fisher v. Waldheim J.G. 1837. Oryctographie du gouvernement de Moscou. Moscou: L'imprimerie d'Auguste Semen. 220 pp.

Formozov A.A. 2007. [Researchers of the Ancientries]. Moscow: Rukopisnye pamiatniki Drevnei Rusi. 184 pp. [In Russian]

Kessler K.F. 1874. [A.P. Fedchenko's Journey to Turkestan: Fish (Pisces)] // Izvestiia OLEAE. Vol.11. No.3. P.1-63 [in Russian].

Knight N. 2001. The Empire on display: Ethnographic exhibition and the conceptualization of human diversity in post-emancipation Russia. NCEER, 814-11g.

Koval' L.M., Teplitskaia A.V. (eds.). 2003. [Staff Members of the Russian State Library. The Moscow Public and Rumiantsev Museums]. Moscow: Pashkov Dom. 220 pp. [in Russian]

Krivosheina G.G. 2013. ["The Society of Destroyers of Naural Science" or "The Moscow Academy of Sciences"? (The $150^{\text {th }}$ anniversary of the Society of Friends of Natural Science, Anthropology, and Ethnography) // Voprosy istorii estestvosnaniia i tekhniki. No 4. P.57-71 [in Russian, with English summary].

Krivosheina G.G. 2014. Long way to the Anthropological Exhibition: The institutionalization of physical anthropology in Russia // Centaurus. Vol. 56. No.4. P.275-304.

Kroneberg A.I. 1875. [A.P. Fedchenko's Journey to Turkestan: Spiders (Araneae)] // Izvestiia OLEAE. Vol.19. No.3. P. 1-58 [in Russian].

Lyubarsky G.Yu. 2009. [The History of the Zoological Museum of the Moscow University: Ideas. People. Departments]. Moscow: KMK Scientific Press. 744 pp. [in Russian]

McLachlan R. 1875. [A.P. Fedchenko's Journey to Turkestan: Lacewings (Neuroptera)] // Izvestiia OLEAE. Vol.19. No.1. P. $1-60$ [in Russian].

Medvedev G.S. 2000. [140th anniversary of the Russian Entomological Society (with portraits of its benefactors and presidents] // Trudy REO. Vol.71. P.6-22 [in Russian].

[Minutes of the meetings of the Society of Friends of Natural Science by the Imperial Moscow University from May 14, 1864 to August 29, 1866]. 1866. // Izvestiia OLEAE. Vol.3. No.1. Col.1-280 [in Russian].

[Minutes of the meetings of the Society of Friends of Natural Science by the Imperial Moscow University from May 14, 1864 to February 1869]. 1886. // Izvestiia OLEAE. Vol.3. No.2. Col.1-330 [in Russian].

[Minutes of the meetings of the Imperial Society of Friends of Natural Science, Anthropology, and Ethnography by the Imperial Moscow University. The seventh year]. 1870. // Izvestiia OLEAE. Vol.8. No.1. Col.1-467 [in Russian].

[Minutes of the meetings of the Imperial Society of Friends of Natural Science, Anthropology, and Ethnography by the Imperial Moscow University. The eighth year]. 1871. // Izvestiia OLEAE. Vol.9. No.1. P.1-137 [in Russian].

Morawitz F.F. 1875. [A.P. Fedchenko's Journey to Turkestan: Bees (Mellifera). Pt.1] // Izvestiia OLEAE. Vol.19. No.2. P.1-160 [in Russian].

Morawitz F.F. 1876. [A.P. Fedchenko's Journey to Turkestan: Bees (Mellifera). Pt.2] // Izvestiia OLEAE. Vol.21. No.3. P.161-304 [in Russian].

Oshanin V.F. 1870. [Materials for the entomology of the governorates of the Moscow Educational District. A list of hemipterous insects of the governorates of the Moscow Educational District] // Izvestiia OLEAE. Vol.6. No.3. Col.1-46 [in Russian].

[Proceedings of the First Congress of Russian Naturalists in St.Petersbourg, held from December 28, 1867 to January 4, 1868]. 1868. St.-Petersbourg: Tip. Imp. AN.1070 pp. with separate pagination [in Russian].

Raikov B.E. 1959. [Anatolii Petrovich Bogdanov] // B.E. Raikov. Russkie biologi-evolutsionisty do Darwina. Vol. 4. MoscowLeningrad: Izdatelstvo AN SSSR. P.203-467 [in Russian].

Reuter O.M.1887. [A.P. Fedchenko's Journey to Turkestan: Hemipterans] // Izvestiia OLEAE. Vol.34. No.4. P.1-39 [in Russian].

Sol'skii S.M. 1874. [A.P. Fedchenko's Journey to Turkestan: Beetles (Coleoptera). Pt.1] // Izvestiia OLEAE. Vol.11. No.5. P. 1222 [in Russian]. 
Sol'skii S.M. 1876. [A.P. Fedchenko's Journey to Turkestan: Beetles (Coleoptera) Pt.2] // Izvestiia OLEAE. Vol.21. No.1. P.223399 [in Russian].

Ul'anin V.N. 1869. [A list of neuropterous and orthopterous insects of the governorates of the Moscow Educational District] // Izvestiia OLEAE. Vol.6. No.2. Col.1-120 [in Russian].

Val'kova O.A. 2006 [Olga Aleksandrovna Fedchenko]. Moscow: Nauka Publ. 318 pp. [In Russian, with English summary]

Val'kova O.A. 2012. [Her Memorial Award: Towards a biography of E.K. Freimut-Kandinskaia] // Priroda. No.4. P.91-95 [in Russian].

Val'kova O.A. 2014. [Women Naturalists of the Russian Empire (late 18th - early 20th)] [Doctoral dissertation]. Moscow. 841 pp. [In Russian]

Vucinich A. 1970. Science in Russian Culture: 1861-1917 Stanford, California: Stanford University Press. 592 pp.

Wagner N.P. 1862. [Spontaneous Reproduction among Insect Larvae]. Kazan: University typography. 50 pp. [In Russian] 